\title{
Challenges of Wilayatul Hisbah and Civil Service Police Unit (Satuan Polisi Pamong Praja) in the Enforcement of Islamic Shari'ah in North Aceh
}

\author{
M. Irsyadi \\ Ph.D Student at Islamic Communication Program, State Islamic University, UINSU, Medan, Indonesia
}

\begin{abstract}
Da'wah to the goodness and forbid the munkar (commanding the good and forbidding the 'evil) is obligatory for every Muslim (mukallaf). It is not only because Islam is a religion of da'wah to invite all human beings to the path of truth and peace but it is also the order of Allah. Wilayatul Hisbah (WH) and Civil Service Police Unit (Satuan Polisi Pamong Praja) in the enforcement of sharia law in Aceh, especially in North Aceh, is always seen as the implementation of da'wah that it is the responsibility for each individual to enforce commanding for good and forbidding the evil. Some challenges which are faced by WH in the enforcement of Islamic Sharia in North Aceh Regency, among others are; ideological challenge, psychological challenges, political challenges, socio-cultural challenge, historical challenges and methodological challenge.
\end{abstract}

Keywords: Islamic shari'ah; da'wah; communication strategy; kaffah

\section{INTRODUCTION}

In Islam, da'wah or appeal to the goodness and forbid the munkar (commanding the good and forbidding the 'evil) is obligatory for every Muslim (mukallaf). It is not only because Islam is a religion of da'wah, to invite all human beings to the path of truth and peace but it is also the order of Allah through His word in QS. Ali Imran: 104:

Meaning: "And let there is a party among you who call to the good of mankind, sent to ma'ruf and prevent it from being unjust, they are the lucky ones." (Surah Al 'Imran: 104).Based on the above verse that it is the obligation to enforce shari'ah (law) of Islam that is 'amar ma'ruf nahi' munkar in every person who recognizes themselves Muslims. However, if there is already a group of people who fulfill this obligation command, then the implicit understanding has been freed of all people. Although, this command applies a common ('am) and valid at all times remained a particular concern among scholars, especially preachers who continue rolling every time missionary activity.

Duties and authorities of Wilayatul Hisbah (WH) and Civil Service Police Unit (Satuan Polisi Pamong Praja) in the enforcement of shari'a law in Aceh, especially in North Aceh, is always seen as the implementation of da'wah that it is the responsibility for each individual to enforce commanding for good and forbidding the evil ". For the WH in Aceh Utara has a special motto that always motivates them namely "Shari'a should be upright even though the sky is falling". However they recognize the challenges in their task quite heavy especially facing among families official staffs and officers which sometimes make violated.Facing this condition, WH and Civil Service Police Unit must take a variety communication strategies in the execution of their duties. The communication strategy is meant here is the patterns, methods, techniques or ways of delivering messages of guidance, advice and awareness about shari'a to the public community, especially those who tend to commit the offense. So that offenders understand, realize and accept shari'a as the law demands, norms and rules base in the lives of Muslims and is committed to not break them.Communication needed in this context is an effective communication, whose messages are always highly appreciated, accepted and managed to change the attitude, behavior, character and mindset (thought) the target. Thus, communication, according to lexicographer (expert in dictionary), refers to a measure aimed shared to achieve unity. The bottom line, is that efforts to cultivate Islamic shari'a in Bumi Tanah Rencong can be well and accepted by all society. 


\section{Definition of Communication Strategy}

\section{METHODOLOGY}

According to Onong Uchjana Effendy, strategy is essentially planning and management to achieve a goal. However, to achieve these objectives, the strategy does not function as a road map that only indicates direction, but must be able to demonstrate how the operational tactics. Similarly, the communication strategy is a communication planning with communication management to achieve its intended purpose. This communication strategy should be able to demonstrate how the practical operations must be carried out, within the meaning of that approach may differ from time to time depending on the circumstances. Success or failure of effective communication activities is determined by the communication strategy. On the other hand, without a communications strategy, an increasingly modern mass media that is now widely used by the States that is growing due to the relative easily obtained and operated, it is not likely to cause negative effects. The communication strategy is a technique or a way of delivering a message that is considered effective to the audience to give effect as expected. The messages are received by the audience at the same time not only from one source, because it takes a special strategy to surpass the struggle so as to effectively achieve the goals expected change in attitude.

\section{DISCUSSION}

As a philosophy given by Chairman of MPU North Aceh, TGK. H. Mustafa Ahmad (Abu Paloh Gadeng) said that in the midst of the people in Aceh consisting of two groups; There is Islam People and there are people in Islam. Meaning: in Aceh, there are people who are really Islam and doing his Islam correctly. This people will receive benefit and happiness in world and hereafter from Allah SWT. But, they are people who are Islam written in their identity card (KTP), because only born from the seed of Islamic family but did not undergo the obligations of Islamic Shari'a, they gain nothing even losses and woe of the world and the hereafter. Likewise with the socialization of Islamic law by personnel of WH in North Aceh, who must face the challenges and obstacles from inside Islam itself, particularly they are just born into Islam, but do not have a sense of belonging to Islam. Discussing the challenges faced by WH personnel in the socialization of the enforcement of Islamic Sharia in the North Aceh can be divided into several forms, including:

\section{a. Ideological Challenge}

This challenge generally comes from non-Muslims. It can be non-Muslims from local in Indonesia and also non-Muslim from another country such as Western countries which are trying to criticize the weaknesses in the enforcement of Islamic Sharia in Aceh, to compare the execution of the sentence the offender to the Human Right (HAM) and democratization. There is a little worry from Christian community to the fate of their relatives who live in Aceh because of the application of Islamic Law in kaffah since 2000 because they are not a believer, and the same religion with the people in Acehl. The problem is, when the Islamic Law enforcement is applied sporadically through the moral movement of certain communities such as students of boarding school, the congregation of remembrance and others, the process often takes place in the violence and coercion regardless of who and what religious people who deal with them.

\section{b. Psychological Challenge}

At least, the public response to the imposition of Islamic Sharia in Aceh is divided into three, namely the full support because they can do worship with safe-comfortable, quiet and exciting. For the contra, they feel it is a kind of disturbances and also for their criminal activities, and shy because during this there is virtually no obligation to pray, although all known forms of such obligations, and capable of doing well. For the third group (who feel shy), it is a challenge for WH personnel, because they are already known and 'alim with the teachings of Islamic faith, so when there is a movement on the consciousness and do all the obligations of Islam, they feel uncomfortable and embarrassed, hence all efforts against the movement done with various forms of resistance. The key is only one "takes awareness and acknowledgment of the truth of Islam". In this group, the name of Islam group hypocrites, one level below the group of infidels or idolaters, because they know Islam, know the obligations and practices of Islam, but are reluctant to do it, even doing abusive in front of nonMuslims. This group becomes a psychological challenge for the enforcement of Islamic Sharia in Aceh, before emerging consciousness to return to the habitat of Muslim, if not then they will continue resistance and hostility towards the enforcement efforts of Islamic Sharia, even more incentive socialization the stronger is the resistance they provide. Ironically, this group is not only a native of Aceh but also migrants who are less happy about the imposition of Islamic Sharia in Aceh, for various reasons and excuses. If those who are from the security forces (TNI/Polri), they often show a selfish attitude towards the WH personnel if they family catch for violating of Islamic Sharia, even they will do violence to WH officers. 


\section{c. Political Challenge}

The application of Islamic Shariah in Aceh as one of the provinces in Indonesia is a complicated problem. Because, in Indonesia, Islamic Sharia is not applied although nearly 95 percent of the citizens are Muslims. Indonesia actually agreed on the concept of a multicultural society, which emphasizes togetherness and harmony with other religions inherited as a motto of "Unity in Diversity". When Aceh by Act No. 44 of 1999 on Privileges Aceh that includes imposition of Islamic Sharia and Law No. 18 of 2001 on Special Autonomy passed, it is carrying a lot of attitude and perception of the community in other areas, both pro- and contra.

For people who support Islamic Law in Aceh, they appreciate and are also struggling to be given also for their area in applying Islamic law such as West Sumatra, Riau, Jambi, Banten, South Kalimantan, Gorontalo and other dominant Islamic population. Meanwhile, the counter often blew negative issues, especially regarding the fate of non-Muslim communities which have already become part of the people in Aceh. This negative issue even up to 16 years (2000-2016) the enforcement of Islamic Sharia in Aceh, still loud sounds.

\section{d. Socio-Cultural Challenge}

Aceh indeed inherits the values and culture of Islam since the seventh century ago from his ancestors, and this teaching is strongly held until the end of time. The principles and values of Islam kaffah (in all aspects of life) live almost in all Acehnese people in terms of cultural, economic, customs, livelihoods, beliefs, politics, arts and social life without any problems. However, when the Islamic Sharia ever imposed across the region at the time of the kingdom of Aceh, uninterrupted time span such a long time and in early 2000 that it is started back with the passage of Act No. 44 of 1999 on Privileges Aceh, many people experience culture shock. At the time, Islamic Shari'a re-incarnated in Aceh, cultural and religious characteristics of the people of Aceh have been many changes by the touch of the popular culture of the West, consequently emerged collisions and frictions, none other than the younger generation in Aceh alone. Not only it, since that, it comes the boundaries between the moderate group with Salafi groups, between Ahlussunnah and Muhammadiyah, the modernist Islamic groups with Salafiah groups, and others. Conflicts among internal groups among Muslims are also a challenge in the implementation of Islamic Shari'a in Aceh, for which a claim to the right while the other group claimed another group of heresy, kurafat and others, as well as cultural differences of sub-ethnics in Aceh who tend not in accordance with the principles of Islamic teachings. This condition generally occurs in the districts that border with North Sumatra, including Aceh Tenggara, Aceh Tamiang and Aceh Singkil.

\section{e. Historical Challenge}

Indonesia challenge is a country built on the basis of Bhinneka Tunggal Ika (different but still one), which is a sign of diversity in national and state life. Since in the era of the struggle for Indonesian independence, we have been jointly live in ethnic diversity, ethnicity, ideology and culture, but they are united by the spirit and ideals of the same, namely the independence of the nation from the invaders. It also implicitly can be seen in the text of Sumpah Pemuda on October 28, 1928, and the text of Pancasila. This commitment is also being sued by many people when Aceh declared themselves with Islamic Shari'a in kaffah (no limit), because historically Aceh also includes in the territory of Republic of Indonesia (NKRI) when the early history of the struggle for independence triggered together. How is it possible, suddenly proclaimed Aceh with Islamic Law which applies to reject non-Muslims from this Bumi Serambi Mekkah? Of course, the attitude of the people of Aceh as it is highly discriminatory! This factor is often faced by personnel of WH in its duty to enforce Islamic Shariah in Aceh including North Aceh regency.. The problem, though Aceh has repeatedly experienced a political conflict that led to separatism with Jakarta, since 1976, 1990 and the last from 1998 to 2005, until today Aceh, are still firmly under the homeland, which originated from the history of the struggle for independence since the start of the insurgencies against Dutch colonialism in $1873-1905$

\section{f. Methodological Challenge}

Another challenge enforcement of Islamic Shari'a in Aceh is a methodological factor, form and shape. Differences of opinion among intellectuals Aceh became sharply in 2010 ago when there were rumors that it was difficult to find the format, method and ideal shape of Islamic Sharia in Aceh. Because the majority of the people of Aceh having mazhab Ahlussunnah waljama'ah (Aswaja), because it cannot be easy to adopt Shari'a formats such as from Saudi Arabia which has mazhab Wahabi, Jordan and Egypt, as well as Brunei Darussalam. Because, apart from schools, cultural characteristics of the people of Aceh are also different from the society of these countries. Therefore, a number of scholars and ulema wish there are consortium formed for that, to do a thorough investigation of Islamic Sharia format appropriate to the culture and characteristics of Acehnese, before it is actually enforced fully. 


\section{CONCLUSION}

Some challenges which are faced by WH in the enforcement of Islamic Sharia in North Aceh Regency, among others are; ideological challenge with an external Islam, psychological challenges from the fasiq group and hypocrite, political challenges with people from other areas because of the Islamic Sharia only in Aceh province alone, the social-cultural challenge due to changes in the native culture of Aceh as a result of exposure to broadcast foreign media for so long, historical challenge for the commitment to struggle for independence and a common fate with the multi-ethnic community and multi-religion and finally, methodological challenges of Islamic scholars and intellectuals about the uniformity of patterns, forms and methods of Islamic Law in Aceh, which should be based on Acehnese people.

\section{REFERENCES}

[1] Abdullah, Irwan. Konstruksi dan Reproduksi Kebudayaan. Jogyakarta: Pustaka Pelajar, 2006Ali Muhammad,Rusydi, Revitalisasi Syariat Islam di Aceh; Problem, Solusi dan Implementasi, Jakarta: ------, Revitalisasi Syari'at Islam di Aceh; Problem, Solusi, dan Implementasi , Cet. I Jakarta: Logos, 2003

[2] ------- Alquran dan Terjemahannya, Bandung : Mizan Bunaya Kreativa, 2001Abbas, Syahrizal, Dimensi Pemikiran Hukum dalam Implementasi Syariat Islam di Aceh, Banda Aceh: Dinas Syari'at Islam, 2007

[3] -------,Paradigma Baru Hukum di Aceh, dalam Kata Pengantar Qanun Aceh Nomor. 7 Tahun 2013 tentang Hukum Acara Jinayat, Banda Aceh: Dinas Syariat Islam, 2014

[4] Azyumardi Azra, dalam Kata Pengantar, Rusjdi Ali Muhammad, Revitalisasi Syariat Islam di Aceh; Problem, Solusi dan Implementasi Jakarta: Logos, 2003

[5] AGHamdani., Akulturasi Budaya dalam Mewujudkan Kerukunan Beragama dan Harmonisasi Sosial, Penelitian Kolektif Kemenag, tahun 2016

[6] -------,Hamdani. Kebebasan Pers Vs Kekerasan terhadap Wartawan. Lhokseumawe: Sefa Bumi Persada, 2015.

[7] Abubakar,Alyasa', Syari'at Islam di Provinsi NAD, Paradigma, Kebijakan dan Kegiatan, Banda Aceh: Dinas Syari'at Islam, 2008

[8] Bungin, Burhan. Sosiologi Komunikasi. Jakarta: Kencana Prenada Media Group, 2006.Badan Pusat Statistik Kabupaten Aceh Utara, Kabupaten Aceh utara Dalam Angka, Lhokseumawe 2016

[9] Bourdieu, Pierre. Arena Produksi Kultural; Sebuah Kajian Sosiologi Budaya. Bantul: Kreasi Wacana, 2010

[10] Baran, Stanley J \& Davis, Dennis K. Teori Dasar Komunikasi Massa. Jakarta: Salemba Humanika \& Cengage, 2009.

[11] -------,Penelitian Kualitatif. Jakarta: Kencana Prenada Media Group, 2007.Cangara, Hafied. Pengantar Ilmu Komuniasi. Jakarta: Raja Grafindo Persada, 2007.

[12] DeFleur, Melvin \& Ball Rokeach, Sandra. Teories of Mass Communication. New York: David McKav, 1975.

[13] Denis McQuail. Mass Communication Theory. Jakarta: Erlangga, 1987.Darma Satrya Sugeng, Aceh Lon : Damai Aceh, Merdeka Abadi, Jakarta, Satker Sementara BRR, 2006

[14] Fajar, Marhaeni. Ilmu Komunikasi Teori \& Praktek. Jakarta: Graha Ilmu \& Univ. Mercu Buana, 2009.Faizah \& Efendi, Lalu Muchsin. Psikologi Dakwah. Jakarta: Kencana Prenada Media Group, 2009.

[15] Fisher, B.Aubrey. Teori-teori Komunikasi. Bandung: Remaja Rosdakarya, 1990Gayo, MH,Perang Gayo - Alas Melawan Kolonial Belanda, Jakarta: Balai Pustaka, 1983

[16] Hafifuddin, Syariat islam dan Tantangan Global, makalah pada Seminar Internasional, 14 Oktober 2011, di Lhokseumawe

[17] -------,Peranan Ulama dalam Pelaksanaan Syariat Islam di Aceh, Jogyakarta: Kaukaba Dipantara STAIN Malikussaleh, 2014

[18] Hasyimy, Cs, 50 Tahun Aceh Membangun, Banda Aceh: MUI Aceh - Percetakan Bali, Medan, 1995Hidayat,Komaruddin, tulisan dalam M.Thoyib, Cs, ed. Sinergi Agama dan Budaya Lokal; Dialektika Muhammadiyah dan Seni Lokal, Surakarta: Muhammadiyah University Press, 2003

[19] Harun, Mohd. Memahami Orang Aceh, dalam Hafifuddin, Peranan Ulama dalam Pelaksanaan Syari'at Islam di Aceh, Jogyakarta: Kaukaba Dipantara, 2014

[20] Husda,Husaini, Sejarah Pemberlakuan Syariat Islam di Aceh, (Dinas Syariat Islam Provinsi Aceh, 2007

[21] Hasan, Erlianan, Komunikasi Pemerintahan, Refika Aditama 2005

[22] Ismail, Azman, Penerapan Syari'at Islam di Nanggroe Aceh Darussalam: tantangan dan Solusi, Banda Aceh: Dinas Syari'at Islam, 2007 
[23] -------,Penerapan Syariat Islam di Nanggroe Aceh Darussalam: Tantangan dan Solusi, Banda Aceh: Dinas Syariat Islam, 2007

[24] Idris,Safwan, "Syariat Islam di Aceh; Reaktualisasi Sejarah Aceh dalam Memasuki Millenium Ketiga, disampaikan pada Seminar Nasional Syariat Islam di Aceh, Banda Aceh, 1999

[25] Kriyantono, Rachmat. Teknik Praktis Riset Komunikasi. Jakarta: Kencana Prenada Media Group, 2006

[26] Kholil, Syukur. Metodologi Penelitian Komunikasi. Bandung: Cita Pustaka Media, 2006.

[27] -------,Teori Komunikasi Massa. Bandung: Cita Pustaka Media, 2011.--------, Komunikasi Islam. Bandung: Cita Pustaka Media, 2007

[28] Lubis, Suwardi. Teori -teori Komunikasi; Sebuah Konsepsi, Analisa dan Aplikasi. Medan: USU Pers, ttLiliweri, Alo. Komunikasi Serba Ada Serba Makna. Jakarta: Kencana Prenada Media Group, 2011

[29] Mufid, Muhamad, Etika dan Filsafat Komunikasi, Jakarta, Kencana 2009

[30] MuzadiHasyim, Sambutan disampaikan pada Seminar Internassional Tahunan Studi Islam, 3 September 2015 di Manado

[31] Mulyana, Deddy. Komunikasi Organisasi, Strategi Meningkatkan Kinerja Perusahaan. Bandung: PTRemajaRosdakarya, 2006

[32] Nuruddin. Pengantar Komunikasi Massa. Jakarta: Raja Grafindo Persada, 2007.Rakhmat, Jalaluddin. Psikologi Komunikasi. Bandung: Remaja Rosdakarya, 2008

[33] Rogers, M. Everet \& Floyd Shoemaker. Communication of Innovation; A Cross Cultural Approach. New York: Free Press Macmilan, 1971.

[34] Rivers, William L, et.al. Mass Media and Modern Society. Jakarta: Kencana Prenada Media Gorup, 2003.Rasyidah, Implementasi Syari'at Islam dalam Paradigma Dakwah, dalam Zaki Fuad Chalil, Melihat Syari’at Islam dari Berbagai Dimenasi, Banda Aceh: Dinas Syari’at Islam, 2007

[35] Rijal, Syamsul et,al, Dinamika dan Problematika Penerapan Syariat Islam, Banda Aceh: Dinas Syariat Islam Provinsi Aceh, 2007

[36] Sjamsu Rijal, et.al, Merajut Damai Berbekal Syari'at Islam, Banda Aceh, Dinas Syari'at Islam Aceh, 2009

-------,Dinamika dan Problematika Penerapan Syari'at Islam, Banda Aceh: Dinas Syari'at Islam Aceh, 2007Saleh, Muhammad,Pelestarian Syari't Islam Melalui Pemberitaan Media, Jurnal Liwa'ul Dakwah, Lhokseumawe: Jur. Dakwah STAIN Malikussaleh, 2014.

[37] Siroj, Said Aqil. Islam Sumber Inspirasi Budaya Nusantara, Jakarta: LTN NU, 2014

[38] Said, Muhammad. Aceh Sepanjang Abad, Jilid II. Medan: 2007 Umar,Muhammad, Darah dan Jiwa Aceh; Mengungkap Falsafah Hidup Masyarakat Aceh, dalam Husaini Husda, Sejarah Pemberlakuan Syariat Islam di Provinsi Nanggroe Aceh Darussalam

[39] Uchjana, Effendy,Onong,Ilmu Komunikasi Teori dan Praktek, Bandung: Remaja Rosdakarya, 1990

[40] --------, Dinamika Komunikasi, Bandung: Remaja Rosdakarya, 2001Widjaja, A.W. Pengantar Ilmu Komunikasi, Jakarta: Bina Aksara, 2001

[41] Internet Sources:

[42] http://farelbae. Wordpress.com/catatan kuliah komuniukasi massa, diakses 18 Januari 2017.http://suksesyahud.blogspot.co.id/2016/03/pengakuan-belanda-terhadap-daya-juang.html, diakses 18 January 2017. 